\title{
VIII ВСЕРОССИЙСКАЯ НАУЧНАЯ КОНФЕРЕНЦИЯ «ХИМИЯ И ТЕХНОЛОГИЯ РАСТИТЕЛЬНЫХ ВЕЩЕСТВ » (7-10 ОКТЯБРЯ 2013 г., КАЛИНИНГРАД)
}

7-10 октября 2013 г. в Калининграде состоялась VIII Всероссийская научная конференция «Химия и технология растительных веществ». Конференция была организована Институтом химии Коми НЦ УрО РАН и Балтийским федеральным университетом им. Иммануила Канта.

Конференция по указанной тематике является регулярной и проводится раз в два года. Ранее конференция проходила в Санкт-Петербурге, Сыктывкаре, Уфе, Казани, Саратове. На конференции рассматриваются актуальные направления химии природных соединений фундаментального и прикладного характера. В рамках конференции регулярно проводится школа молодых ученых.

Научная программа VIII Всероссийской конференции «Химия и технология растительных веществ» включала доклады по следующим направлениям:

1. Изучение состава низкомолекулярных компонентов растительного сырья; синтез аналогов и производных природных соединений.

2. Биологическая функция и физиологическая активность растительных веществ.

3. Лесохимия - технология веществ и материалов.

Сборник материалов VIII Всероссийской конференции «Химия и технология растительных веществ» состоит из 266 тезисов. Список авторов докладов включает 661 человека из России, Белоруси, Казахстана, Украины, Узбекистана, Киргизии, Азербайджана, Грузии, Монголии.

Очное участие в работе конференции приняли более 100 ученых, среди которых 4 членакорреспондента РАН, 25 докторов наук, 42 кандидата наук, научные сотрудники, аспиранты.

С приветствием к участникам конференции выступили проректор по научной работе Балтийского федерального университета им. И. Канта, профессор А.В. Юров, председатель организационного комитета конференции, член-корр. РАН А.В. Кучин.

На конференции были представлены работы ученых академических институтов и вузов из Калининграда (Балтийский федеральный университет), Архангельска (Северный (Арктический) федеральный университет им. М.В. Ломоносова), Барнаула (Алтайский государственный университет), Бийска (Институт проблем химико-энергетических технологий СО РАН), Екатеринбурга (Ботанический сад УрО РАН), Иванова (Институт химии растворов им. Г.А. Крестова РАН), Иркутска (Иркутский государственный университет, Иркутский институт химии им. А.Е. Фаворского СО РАН), Казани (Институт органической и физической химии им. А.Е. Арбузова КазНЦ РАН, Казанский институт биохимии и биофизики КазНЦ РАН, Казанский национальный исследовательский технологический университет), Красноярска (Сибирский государственный технологический университет), Москвы (Институт биохимической физики им. Н.М. Эмануэля РАН, Институт органической химии им. Н.Д. Зелинского РАН, Московский государственный университет им. М.В. Ломоносова, Московский педагогический государственный университет), Нижнего Новгорода (Нижегородский государственный технический университет им. Р.Е. Алексеева), Новосибирска (Центральный сибирский ботанический сад СО РАН), Пущино (Институт биохимии и физиологии микроорганизмов им. Г.К. Скрябина РАН), Санкт-Петербурга (Институт высокомолекулярных соединений РАН, Санкт-Петербургский государственный лесотехнический университет им. С.М. Кирова, Санкт-Петербургский государственный технологический институт (технический университет)), Сыктывкара (Институт биологии Коми НЦ УрО РАН, Институт физиологии Коми НЦ УрО РАН, Институт химии Коми НЦ УрО РАН), Тольятти (Институт экологии Волжского бассейна РАН), Уфы (Институт нефтехи- 
мии и катализа РАН, Институт органической химии УНЦ РАН), Якутска (Северо-Восточный федеральный университет), Владивостока (Дальневосточный федеральный университет, Институт химии ДВО РАН, Тихоокеанский институт биоорганической химии им. Г.Б. Елякова ДВО РАН).

Кроме российских ученых в конференции принимали участие ученые из Беларуси (Институт биоорганической химии НАН Беларуси) и Казахстана (Казахский национальный университет им. Аль-Фараби, Международный научно-производственный холдинг «Фитохимия»).

Во время работы конференции было представлено и обсуждено 15 пленарных докладов и лекций, 39 устных секционных и 60 стендовых докладов.

В рамках конференции состоялась презентация информационного ресурса SciFinder он-лайн системы Chemical Abstracts Service (Mr. Veli-Pekka Hyttinen, региональный представитель CAS по Центральной и Восточной Европе).

\section{VIII Всероссийская конференция «Химия и технология растительных веществ» Решение}

Данная конференция затрагивает комплекс вопросов в области переработки растительного сырья, включая химические аспекты выделения, изучения состава, биологической и физиологической активности растительных веществ, создание на их основе новых перспективных материалов, а также синтеза аналогов природных соединений. Всестороннее изучение растительных веществ представляет собой актуальное научное направление, имеющее очень большое фундаментальное значение с очевидной перспективой практического применения в самых различных областях деятельности человека.

Участники конференции отмечают высокий уровень и актуальность представленных докладов и сообщений, широкий круг рассмотренных вопросов. Представленные доклады отличались существенной новизной, высоким уровнем и отражали достижения в области фундаментальных и прикладных исследований по химии и технологии растительных веществ. Результаты, полученные авторами, уже находят применение в практике или могут быть рекомендованы к использованию.

\section{Участники конференции решили:}

1. Одобрить работу VIII Всероссийской конференции «Химия и технология растительных веществ».

2. Считать целесообразным продолжение работ в области всестороннего изучения и практического применения растительных веществ.

3. Признать правильным организацию и проведение в рамках конференции Школы по биоорганической химии и химии природных соединений для молодых ученых, работающих в данной и смежных областях науки.

4. Обратить особое внимание на максимально возможную интеграцию усилий академической, вузовской и отраслевой науки.

5. Рекомендовать докладчикам представить материалы для опубликования в журналах «Известия Академии наук. Серия химическая» и «Химия растительного сырья».

6. Провести IX Всероссийскую конференцию «Химия и технология растительных веществ» через 2 года на базе ФГБУН Института биохимической физики Н.М. Эмануэля Российской академии наук (г. Москва).

Принято единогласно на заключительном заседании участников конференции 10 октября 2013 г.

Конференция проходила при поддержке Российского фонда фундаментальных исследований (проект №13-03-06-063); Российского химического общества им. Д.И. Менделеева; информационного ресурса SciFinder (Chemical Abstracts Service); 3AO «Маркетинг-Бюро» (Киров). 